\title{
The Impact Of Psychological Empowerment On Work Engagement Among University Faculty Members In China
}

This article was published in the following Dove Press journal: Psychology Research and Behavior Management

\section{Qian Meng (D) \\ Fangfang Sun}

Department of Higher Education, College of Education, Bohai University, Jinzhou

121013, People's Republic of China
Correspondence: Qian Meng Department of Higher Education, College of Education, Bohai University, $19 \mathrm{Keji}$ Road, Jinzhou I21013, People's Republic of China

Tel/fax +864163400230

Email mengqian_china@hotmail.com
Background: The primary aim of this research was to examine the role of psychological empowerment on the work engagement of university faculty members in China and the implications for both faculty members and university administrators. The questions of the study focus on the level of psychological empowerment and work engagement of university faculty members and the correlation between psychological empowerment and work engagement.

Materials and methods: Data were collected from a sample of 162 faculty members working at a China university. They were asked to complete two self-reported scales with good reliability and validity: the psychological empowerment scale (PES) and the Utrecht work engagement scale (UWES). The responses from the sample were analyzed using SPSS software. The descriptive statistics showed the participants' statistical characteristics, while independent sample $t$-tests and one-way analysis of variance (ANOVA) revealed group differences among university faculty members. Correlation analysis and multidimensional regression analysis demonstrated how psychological empowerment affected work engagement.

Results: The total scores for the PES and UWES were both moderately high. Gender, age, degree attained, and professional ranking were associated with differences in levels of psychological empowerment and work engagement. The results confirmed that psychological empowerment was positively correlated with all the dimensions of work engagement. The regression analysis results showed that the positive role of psychological empowerment in work engagement was mainly realized through two dimensions: meaning and competence.

Conclusion: The study results revealed significant group differences in the PES and UWES scores among university faculty members. Universities should give more support to younger and junior faculty. There is highly positive correlation between psychological empowerment and work engagement. University should recognize the role of psychological empowerment and create a supportive environment to promote faculty members' professional development, which, in turn, can increase universities' productivity.

Keywords: psychological empowerment, work engagement, faculty members, case study

\section{Introduction}

Psychological empowerment is a concept originating from industrial-organizational psychology. Empowerment is defined as the opportunity an individual has for autonomy, choice, responsibility, and participation in decision making in organizations. ${ }^{1}$ Psychological empowerment refers to an "intrinsic task motivation reflecting a sense of self-control in relation to one's work and an active engagement with one's work role.",2 Many studies on enterprise organizations have found that psychological empowerment 
can effectively stimulate individuals' enthusiasm for work and promote the improvement of job performance. Psychological capital influences job satisfaction and organizational commitment. ${ }^{3}$ Whereas engagement seems to be contagious and may spread across members of work teams, leaders have a special role in fostering work engagement among their followers. ${ }^{4}$ Authentic leadership has been proposed as the root element of effective leadership needed to build healthier work environments because there is special attention to the development of empowering leader-follower relationships. 5

Since the 1980s, an increased interest in empowerment has been seen in diverse subject areas within psychology and management. Psychology empowerment linked empowering leadership to job satisfaction, work effort, and creativity. ${ }^{6}$ Structural empowerment had a direct positive effect on the areas of work life, which in turn had a direct negative effect on emotional exhaustion. Subsequently, emotional exhaustion had a direct negative effect on commitment. ${ }^{7}$ A survey of 258 respondents showed that psychological empowerment has an important role in positive work outcomes. ${ }^{8}$ Statistically significant relationships were found between psychological empowerment, job insecurity and employee engagement. ${ }^{9}$ Employees were highly engaged when they had higher psychology capital, work empowerment partially mediated the relationship between psychology capital and work engagement. ${ }^{10}$ Research has demonstrated that psychological empowerment is positively related to employees' task, contextual, and innovation performance. ${ }^{11}$ Employees' perceptions of their leaders' empowering behavior and psychological empowerment predict employees' intention to leave organizations. ${ }^{12}$ Empowerment is a key variable in predicting positive organizational outcomes. ${ }^{13}$ At present, the concept of psychological empowerment and its structure have been recognized by most scholars. The conceptual structure of psychological empowerment proposed by Thomas et al is widely accepted. ${ }^{14}$ They believe that psychological empowerment is a combination of four cognitive components: a sense of impact, competence, meaningfulness, and choice.

In the past few years, higher education is in transition along many dimensions: tuition levels, faculty composition, expenditure allocation, pedagogy, technology, and more. ${ }^{15}$ Universities were facing many challenges, including massification, increasing internationalization, growing emphasize on the applicability of academic work and the rising influence of management, which have reshaped university culture. ${ }^{16}$ University faculty members are under pressure from quality requirement, demanding from the public, funding reduction from government and new technological demands. ${ }^{17}$ Faculty members, as the main actors in colleges and universities, are one of the decisive factors in improving the quality of teaching, scientific research, and social service in universities. Faculty's work engagement is a predictive of performance. ${ }^{18}$ Performance management provides external institutional constraints and incentives for individual faculty members. As an internal incentive, psychological empowerment helps stimulate faculty members' enthusiasm for work and increases their level of work engagement. ${ }^{19}$ The most influential dimension of empowerment predicting teacher intrinsic satisfaction is self-efficacy, a psychologically oriented variable. ${ }^{20}$ Faculty members with higher levels of empowerment tend to have higher job performance, be more motivated in their teaching and research, be more likely to actively explore effective teaching methods, and be more willing to discuss problems encountered in their teaching and research with leaders. ${ }^{21}$

Based on the findings of previous research, this study attempts to explore university faculty members' level of psychological empowerment and its impact on work engagement. As a changing organization, universities often face unexpected risks. Psychological empowerment and affective commitment are considered to be especially important in such a turbulent context that requires continuing contributions from employees.

\section{Materials And Methods}

\section{Sample}

This study was conducted at a China public university that was undergoing a series of changes and challenges aimed at improving the quality of teaching and research and the university's ranking. A random sample was chosen for the study, and participation was completely voluntary. A total of 180 questionnaires were distributed, and 162 valid questionnaires were answered. The effective response rate is $90 \%$. Of the 162 participants with valid responses: a) $62.96 \%$ were women; b) $3.70 \%$ were younger than 30 years old, $74.08 \%$ were $30-50$ years old, and $22.22 \%$ were older than 50 years; c) $19.75 \%$ were professors, $44.44 \%$ were associate professors, and $35.80 \%$ were assistant professors; and d) 38.27\% held doctoral degrees, $56.79 \%$ held master degrees, and $4.94 \%$ held bachelor degrees. Retired and part-time faculty were excluded from the sample. In accordance with the Declaration of Helsinki, written informed consent was provided by the participants prior 
to filling the questionnaire. The study was approved by the Ethical Committee of Bohai University. The anonymity of the participants was preserved. Participants can fully and freely express their opinions.

The sample's demographic information is given in Table 1 . A Mann-Whitney $U$-test was run to determine if there were differences in gender, degree, age and profession ranking between sample distribution and population distribution. The results showed that there were no statistically significant difference between them $(p>0.1)$. The trend of sample distribution is consistent with that of population distribution. Sample can adequately represent population.

\section{Procedure}

This study was conducted between March 2019 and May 2019. The participants were recruited at random from a China university. We stated the purpose of the questionnaire and assured the participants that their answers would remain confidential. Participants will be provided with a verbal overview about research objectives and information to ensure all the details of the project have been understood. The participants were asked to complete a paper

Table I Distribution Of Faculty In Sample

\begin{tabular}{|l|l|l|}
\hline & Frequency & Percent \\
\hline $\begin{array}{l}\text { Gender } \\
\text { Male }\end{array}$ & 60 & \\
Female & 102 & 37.04 \\
\hline Age & & 62.96 \\
$20-30$ & 6 & \\
$31-40$ & 38 & 3.70 \\
$41-50$ & 82 & 23.46 \\
$50+$ & 36 & 50.62 \\
\hline Degree & & 22.22 \\
Doctor & 62 & \\
Master & 92 & 38.27 \\
Bachelor & 8 & 56.79 \\
\hline Professional ranking & & 4.94 \\
Professor & 32 & \\
Associate professor & 72 & 19.75 \\
Assistant professor & 58 & 44.44 \\
\hline Length of teaching (years) & & 35.80 \\
$0-3$ & 4 & \\
$3-9$ & 24 & 2.47 \\
$9-15$ & 38 & 14.81 \\
I5+ & 96.26 \\
\hline Total & 162 & \\
\hline
\end{tabular}

questionnaire and were informed of their right to withdraw from the study if they felt uncomfortable. The participants were told that they had the right to refuse to answer any particular question and no participants would be named in the publications, and every effort would be made to disguise their identity. In the last part of the questionnaire, the participants had the option to leave their e-mail address if they were interested in receiving a summary of the results. These steps fully guaranteed the rationality and integrity of data and meanwhile protected participants' privacy and rights. For more information or raw data, please contact the authors.

\section{Method}

All participants were asked to complete two self-reported scales with good reliability and validity: the psychological empowerment scale (PES) and the Utrecht work engagement scale (UWES). The psychological empowerment scale (PES) was developed by Spreitzer ${ }^{22}$ and adapted for the Chinese context by Li Chaoping. ${ }^{23}$ The scale had 12 items grouped into four dimensions: meaning ( 3 items), competence (3 items), self-determination ( 3 items), and impact ( 3 items). The scale was based on a 5-point Likert scale (1=strongly disagree, $2=$ disagree, $3=$ not sure, $4=$ agree, $5=$ strongly agree). Higher scores indicated higher levels of psychological empowerment. The scale had good reliability and validity. The internal consistency coefficients of the meaning, competence, self-determination and impact sub-scales were 0.68 , $0.53,0.42$, and 0.78 , respectively, and the internal consistency coefficient of the overall scale was 0.87 .

The Utrecht work engagement scale (UWES) was developed by Schaufeli and Bakker ${ }^{24}$ and revised by Zhang Yiwen and Gan Yiqun. ${ }^{25}$ The Chinese version of UWEShad15 items grouped into three dimensions: vitality (6 items), dedication (4 items), and focus (5 items). All the questions were also scored on a 5-point Likert scale (1=complete non-conformity, $2=$ non-conformity, $3=$ not sure, $4=$ conformity, $5=$ complete conformity). Higher scores indicated higher levels of work engagement. The internal consistency coefficients of the vitality, dedication and focus sub-scales were $0.84,0.78$, and 0.86 , respectively, and the internal consistency coefficient of the scale was 0.94 , indicating good reliability and validity.

All the data were analyzed with SPSS 20.0. The descriptive statistics showed the participants' statistical characteristics, while independent sample $t$-tests and oneway analysis of variance (ANOVA) revealed group differences among university faculty members. Correlation 
analysis and multidimensional regression analysis demonstrated how psychological empowerment affected work engagement.

\section{Results}

\section{Psychological Empowerment Scores Of University Faculty Members}

As can be seen in Table 2, university faculty members' total score for psychological empowerment was 3.7263 which falls into moderately high level. The scores for the four dimensions exhibited no significant differences (meaning: $\mathrm{M}=4.44$, $\mathrm{SD}=0.55$; self-determination: $\mathrm{M}=3.92, \mathrm{SD}=0.84$; competence: $\mathrm{M}=4.02, \mathrm{SD}=0.51$; impact, $\mathrm{M}=2.53, \mathrm{SD}=0.85$ ). The dimension with the highest score was work meaning, followed by competence and self-determination, while work impact had the lowest score.

Similar results were found in the UWES (Table 3). The overall UWES score was at an upper-middle level, and there were little differences among the three dimensions. Each dimension had a score higher than 3.5. Focus had the highest score, followed by vitality and then concentration.

\section{Group Differences In The Psychological Empowerment And Work Engagement Of University Faculty}

In order to analyze the differences in psychological empowerment and work engagement among various groups of university faculty members, we used gender, age, degree attained, professional ranking and length of teaching as grouping variables. Psychological empowerment and work engagement were dependent variables, respectively. The results are shown in Table 4.

As can be seen from the above table, there are significant gender differences emerged in the PES and UWES scores, with male faculty members having significantly higher scores than that of female faculty members. There were also significant age differences in the PES scores but no significant differences in the UWES scores. The results of post-test showed that faculty members more than 50 years old had higher psychological empowerment levels than those ages $20-30,31-40$, and $41-50$ years $(p=0.002$, $p=0.002, p=0.000$, respectively). The degree attained variable showed significant differences in the PES and UWES scores among faculty members holding bachelor, master, and doctoral degrees. In the post-test results, faculty members with doctoral degrees had significantly higher scores than those with master and bachelor degrees $(p=0.000$, $p=0.019$ ). In addition, professional ranking was also an important variable, with professors scoring higher on both scales than associate and assistant professors.

\section{Regression Analysis Of The Dimensions Of Psychological Empowerment On Work Engagement}

To further test the relationship between psychological empowerment and work engagement, we performed correlation analysis. As shown in Table 5, psychological empowerment was positively correlated with all the dimensions of work engagement. The analysis showed that psychological empowerment levels were closely related to work engagement.

We then performed stratified regression to separately examine the impacts of the four dimensions of psychological empowerment on work engagement. The first step was to explore the influence of demographic variables. The second step was to test the four dimensions of psychological empowerment. As shown in Table 6, when controlling for demographic variables, four variables (meaning, determination, competence and impact) predicted $57.7 \%$ of the variance of work engagement, while the contributions of meaning and competence reached to significant level. Meaning and competence both had significantly positive effects on the total score and the three dimensions of work engagement. Determination and impact had no significant effects on the total score or any dimension.

\section{Discussion}

The results showed that while university faculty members had higher than middle levels of psychological empowerment, the scores for the four dimensions were unequal. Meaning had the highest score $(\mathrm{M}=4.44)$, and impact had the lowest $(\mathrm{M}=2.52)$. The high score for meaning indicated that university faculty members clearly understood the

Table 2 Scores For Four Dimensions Of Psychological Empowerment Of University Faculty Members

\begin{tabular}{|l|l|l|l|l|l|}
\hline & Meaning & Self-Determination & Competence & Impact & Total \\
\hline M & 4.4444 & 3.9177 & 4.0165 & 2.5267 & 3.7263 \\
SD & 0.55277 & 0.83920 & 0.51343 & 0.84961 & 0.57769 \\
\hline
\end{tabular}


Table 3 Scores For Three Dimensions Of Work Engagement Of University Faculty Members

\begin{tabular}{|l|l|l|l|l|}
\hline & Vitality & Dedication & Focus & Total \\
\hline M & 3.6975 & 3.6944 & 4.0025 & 3.7984 \\
SD & 0.74913 & 0.71041 & 0.67933 & 0.68068 \\
\hline
\end{tabular}

Table 4 Group Differences On Psychological Empowerment And Work Engagement Among University Faculty Members

\begin{tabular}{|c|c|c|c|}
\hline & & $\begin{array}{l}\text { Psychological } \\
\text { Empowerment }\end{array}$ & $\begin{array}{l}\text { Work } \\
\text { Engagement }\end{array}$ \\
\hline Gender & $\begin{array}{l}\text { Male }(60) \\
\text { Female }(102) \\
t\end{array}$ & $\begin{array}{l}4.00 \pm 0.11 \\
3.57 \pm 0.07 \\
3.491 * *\end{array}$ & $\begin{array}{l}4.06 \pm 0.14 \\
3.64 \pm 0.08 \\
2.812^{* *}\end{array}$ \\
\hline Age & $\begin{array}{l}20-30(6) \\
3 I-40(38) \\
4 I-50(82) \\
5 I+(36) \\
F\end{array}$ & $\begin{array}{l}3.19 \pm 0.10 \\
3.65 \pm 0.13 \\
3.59 \pm 0.08 \\
4.21 \pm 0.14 \\
7.483 * *\end{array}$ & $\begin{array}{l}3.13 \pm 0.21 \\
3.75 \pm 0.18 \\
3.74 \pm 0.09 \\
4.10 \pm 0.17 \\
2.436\end{array}$ \\
\hline Degree & $\begin{array}{l}\text { Bachelor (8) } \\
\text { Master (92) } \\
\text { Doctor (62) } \\
F\end{array}$ & $\begin{array}{l}3.35 \pm 0.23 \\
3.55 \pm 0.07 \\
4.03 \pm 0.11 \\
8.473^{* *}\end{array}$ & $\begin{array}{l}3.77 \pm 0.43 \\
3.62 \pm 0.08 \\
3.80 \pm 0.08 \\
5.190 * *\end{array}$ \\
\hline $\begin{array}{l}\text { Professional } \\
\text { Ranking }\end{array}$ & $\begin{array}{l}\text { Assistant } \\
\text { professor (58) } \\
\text { Associate } \\
\text { professor (72) } \\
\text { Professor (32) } \\
\text { F }\end{array}$ & $\begin{array}{l}3.39 \pm 0.08 \\
3.78 \pm 0.5 \mid \\
4.21 \pm 0.14 \\
\mid 4.883^{* *}\end{array}$ & $\begin{array}{l}3.53 \pm 0.13 \\
3.87 \pm 0.10 \\
4.12 \pm 0.70 \\
3.484^{*}\end{array}$ \\
\hline $\begin{array}{l}\text { Length of } \\
\text { Teaching }\end{array}$ & $\begin{array}{l}0-3 \text { years }(4) \\
3-9 \text { years }(24) \\
9-15 \text { years }(38) \\
15+\text { years }(96) \\
F\end{array}$ & $\begin{array}{l}3.13 \pm 0.13 \\
3.53 \pm 0.16 \\
3.64 \pm 0.13 \\
3.83 \pm 0.08 \\
1.936\end{array}$ & $\begin{array}{l}3.10 \pm 0.37 \\
3.58 \pm 0.21 \\
3.90 \pm 0.15 \\
3.84 \pm 0.97 \\
1.372\end{array}$ \\
\hline
\end{tabular}

Note: $* P<0.05, * * p<0.01$.

purpose and value of education. The scores for self-determination and competence indicated that university faculty members were willing to work independently and conscientiously and were confident in their ability to execute the teaching and research tasks. However, the lowest score for impact implied that university faculty members felt they had little influence on university management and seldom participated in the decision-making process, so they did not recognize that their opinions were highly important and influential in university development. In addition, the UWES scores of 3.5-4.0 indicated that the university faculty had high professional identity and loved their work.
The results revealed significant gender differences in the PES and UWES scores. Male faculty members had significantly higher scores than female members, conflicting with the results of related research. ${ }^{26}$ In Chinese traditional culture, the idea that men go out to work while women look after the house has created higher social expectations for the achievements of men than women.

The study found that age was also a key variable influencing faculty members' beliefs. ${ }^{27}$ Older faculty members had higher PES scores because they had worked at the university longer than younger faculty. They had witnessed the development of the university, so they had a deeper feeling for the university and a stronger sense of identity and belonging.

The analysis also revealed significant differences in scores for the two scales by degree attained. Faculty members with higher degrees had higher PES and UWES scores, consistent with previous research conclusions. ${ }^{11}$ This difference arose because faculty members with doctoral degrees had higher work expectations, values, and goals than those with master and bachelor degrees and, therefore, were more involved in their work. In addition, the university regarded faculty members with doctoral degrees as valuable resources for future productivity growth and so gave them more autonomy and flexibility in their work.

The PES and UWES total scores showed significant differences by professional ranking, as found in previous studies. ${ }^{28}$ Professors had significantly higher scores than associate and assistant professors. Due to their longer teaching experience, greater breadth and depth of knowledge, and higher professional skills, professors were more confident in their work and experienced a higher sense of control.

Psychological empowerment was a predictor of work engagement. ${ }^{29}$ One of the main reasons for the strong attention to psychological empowerment is that it can improve work engagement, which the relevant analysis and regression analysis supported in this research. The relevant analysis showed that psychological empowerment was closely related to work engagement, while the regression analysis found that the positive role of psychological empowerment on work engagement was mainly realized through two dimensions: meaning and competence. University faculty members were aware of the value and significance of their work to promote student growth and school development and were capable of completing tasks, leading them to be more involved in work.

However, self-determination and work impact did not show good positive roles in promoting the level of work engagement. These results might be due to the growing 
Table 5 The Correlation Between Psychological Empowerment And Work Engagement

\begin{tabular}{|c|c|c|c|c|c|c|c|c|c|}
\hline & Meaning & Self-Determination & Competence & Impact & Totall & Vitality & Dedication & Focus & Total2 \\
\hline Meaning & I & & & & & & & & \\
\hline Self-Determination & $0.646 * *$ & I & & & & & & & \\
\hline Competence & $0.57 I^{* *}$ & $0.642^{* *}$ & I & & & & & & \\
\hline Impact & $0.468 * *$ & $0.593 * *$ & $0.668 * *$ & 1 & & & & & \\
\hline Totall & $0.773 * *$ & $0.878 * *$ & $0.847 * *$ & $0.844 * *$ & I & & & & \\
\hline Vitality & $0.647^{* *}$ & $0.630 * *$ & $0.679 * *$ & $0.513^{* *}$ & $0.723 * *$ & I & & & \\
\hline Dedication & $0.716 * *$ & $0.518 * *$ & $0.614 * *$ & $0.487^{* *}$ & $0.675^{* *}$ & $0.877^{* *}$ & I & & \\
\hline Focus & $0.638 * *$ & $0.515^{* *}$ & $0.614 * *$ & $0.493 * *$ & $0.657^{* *}$ & $0.810 * *$ & $0.884^{* *}$ & I & \\
\hline Total2 & $0.697 * *$ & $0.593 * *$ & $0.674 * *$ & $0.526 * *$ & $0.725^{* *}$ & $0.956 * *$ & $0.963^{* *}$ & $0.935^{* *}$ & I \\
\hline
\end{tabular}

Notes: $* * P<0.01$, Totall means the score of psychological empowerment scale, Total2 means the score of work engagement scale.

Table 6 Multidimensional Regression Analysis Of University Faculty Members' Psychological Empowerment On Work Engagement

\begin{tabular}{|c|c|c|c|c|c|c|c|c|}
\hline \multirow[t]{2}{*}{ Variables } & \multicolumn{2}{|c|}{ Vitality $(\beta)$} & \multicolumn{2}{|c|}{ Dedication $(\beta)$} & \multicolumn{2}{|c|}{ Focus $(\beta)$} & \multicolumn{2}{|l|}{ Total $(\beta)$} \\
\hline & Step I & Step 2 & Step I & Step 2 & Step I & Step 2 & Step I & Step 2 \\
\hline Gender & -0.175 & 0.131 & -0.210 & -0.050 & -0.210 & -0.055 & -0.205 & -0.040 \\
\hline Age & 0.120 & 0.133 & 0.091 & 0.022 & 0.127 & 0.018 & 0.121 & -0.003 \\
\hline Degree & 0.163 & 0.123 & 0.090 & 0.055 & 0.152 & 0.107 & 0.147 & 0.074 \\
\hline Professional ranking & 0.120 & 0.100 & 0.142 & -0.152 & 0.100 & -0.163 & 0.126 & -0.149 \\
\hline Length of teaching & -0.001 & 0.118 & -0.007 & -0.035 & -0.061 & -0.063 & -0.023 & -0.028 \\
\hline Meaning & & $0.147^{* *}$ & & $0.611^{* *}$ & & $0.48 I^{* *}$ & & $0.479 * *$ \\
\hline Self-determination & & 0.110 & & -0.109 & & -0.078 & & 0.012 \\
\hline Competence & & $0.180 * *$ & & $0.303 * *$ & & $0.356 * *$ & & $0.383^{* *}$ \\
\hline Impact & & 0.101 & & 0.097 & & 0.099 & & 0.073 \\
\hline$F$ & $2.732 *$ & $18.952^{* *}$ & $2.34 I$ & $20.659 * *$ & $2.58 I^{*}$ & $15.095^{* *}$ & $2.840 *$ & $21.98 I^{* *}$ \\
\hline$R^{2}$ & 0.154 & 0.437 & 0.077 & 0.550 & 0.087 & 0.479 & 0.103 & 0.577 \\
\hline
\end{tabular}

Notes: $* P<0.05, * * P<0.01$.

distance between academics and administrators. ${ }^{30}$ Governance models around the world vary by culture, history, political structure, and institutional traditions. ${ }^{31}$ As in the 1940s, when faculty employment principles were developed by the American Association of University Professors and accepted generally by the higher education community, faculty today still value academic freedom, shared governance, and job security as important components of the academic profession. ${ }^{32}$ Share governance is a myth. ${ }^{33}$ Yet while it has been a time-honored tradition in academia, the shared governance model has always had its problems, not least of which is the very nature of the faculty who must work with administrators if the model is going to succeed. ${ }^{34}$ Share governance plays an important role in integrating sustainability into university. ${ }^{35}$ The emphasis on accountability has made efficiency become the dominant value of university decision making in which faculty members seldom participate. University faculty members thought that they had to abide by rules and regulations made by administrators, they felt weak senses of self-determination and work impact. This situation could explain why self-determination and work impact did not have positive effects on work engagement.

Due to the slow growth of government investment in universities and the emphasis on university performance, work engagement is of interest to researchers and practitioners. More than over, universities need more engaged faculty members. Past studies have established the importance of psychological empowerment in fostering innovative behavior. ${ }^{36}$ Research shows that employees with higher degree of psychological empowerment will be motivated to work harder and their performance will be correspondingly higher. ${ }^{37}$ The finding of this study can provide valuable inspiration not only to university faculty members but also to deans, managers and instructors.

\section{Conclusion}

The study results revealed significant group differences in the PES and UWES scores among university faculty 
members. Creating a work environment that fosters meaningful work experiences encourages employee's sense of competence, their self-determination and an awareness of the impact of one's work, which in turn promotes beneficial outcomes within organizations. ${ }^{11}$ Opportunities for advancement and research support, as well as responsiveness of administrators to faculty, contributed to the faculty commitment. $^{38}$

Universities, therefore, should create a supportive environment to promote the professional development of younger and junior faculty, which will result in higher levels of psychological empowerment and work engagement and thus greater productivity for universities. Creating supportive and empowering workplace conditions are important not only for faculty health and wellbeing but also for retaining top-performing faculty. ${ }^{39}$

Psychological empowerment had a close correlation with work engagement, aligning with earlier research. ${ }^{6}$ Authority grants not only power granting, but also ability granting. University faculty members are typical representatives of knowledgeable workers who pay great attention to realize their own values and attach high importance to whether enterprises can provide opportunities for knowledge growth. Deans and heads of departments can take advantage of the results of this study when evaluating the performance of faculty members in university. Administrators should recognize the importance of psychological variables. ${ }^{3}$ For faculty members, the more institutional and unit support they perceived for learning, the more satisfied they were, the less likely they were to intend to leave their institution. ${ }^{40}$ University should give opportunities to professional and academic growth of faculty members. University faculty members are more active in their work when they realize the importance and trust they have received from universities.

These results are suggestive rather than definitive due to the study's limitations. First, the participants were from one university, decreasing the generalizability of the results. In future research, we will increase the sample size to verify the reliability of the conclusions. Second, this study relied on only two scales to measure psychology empowerment and work involvement; in-depth interviews with selected participants could be helpful to more deeply understand the issues at involved. Third, certain variables related to the participants (e.g. their economic, social, and psychological backgrounds) could not be controlled for and so could have influenced their responses. Fourth, the data were self-reported, so the results might not truly reflect the relevance between psychology empowerment and work involvement.

Despite of these limitations, this study makes theoretical and practical contributions to the growing body of literature on university faculty members' work performance. The study can provide worthy and useful insights for other universities. In other words, this finding can assist universities to maintain high levels of psychological empowerment and commitment to universities among faculty members, in turn, enhancing universities' own performance and effectiveness.

\section{Acknowledgments}

This article is the result of the project "Right Expression and Interest Claim: A Study on the Power Structure of University Governance Based on Organizational Efficiency," supported by the National Office for Education Science Planning (No. CIA150186). Our special thanks go to all the research participants.

\section{Disclosure}

The authors report no conflicts of interest in this work.

\section{References}

1. Lightfoot SL. On goodness of schools: themes of empowerment. Peabody J Educ. 1986;63(3):9-28. doi:10.1080/01619568609538522

2. Scott ES, Gang W, Stephen HC. Antecedents and consequences of psychological and team empowerment in organizations: a meta-analytic review. J Appl Psychol. 2011;96(5):981-1003. doi:10.1037/ a0022676

3. Omar D, Moinuddin A, Al-Tobasi A, et al. The impact of the psychological capital on job performance: a case study on faculty members at Philadelphia University. Int Rev Manag M. 2016;6 (2):183-191.

4. Arnold BB, Simon LA, Michael PL. Key questions regarding work engagement. Eur $J$ Work Organ Psychol. 2011;20(1):4-28. doi:10.1080/1359432X.2010.485352

5. Carol AW, Heather KL. Authentic leadership, performance, and job satisfaction: the mediating role of empowerment. J Adv Nurs. 2013;69(4):947-959. doi:10.1111/j.1365-2648.2012.06089.x

6. Stein A, Øyvind LM. Linking empowering leadership to job satisfaction, work effort, and creativity: the role of self-leadership and psychological empowerment. J Leadersh Org Stud. 2015;22(3):304323. doi: $10.1177 / 1548051814565819$

7. Julia C, Heather KS, Carol W. Workplace empowerment, work engagement and organizational commitment of new graduate nurses. Nurs Leadersh. 2006;19(3):43-60. doi:10.12927/cjnl.2006.18368

8. Irina M, Coralia S, Paul S. Engaged, committed and helpful employees: the role of psychological empowerment. J Psychol. 2015;149 (3): 1-14. doi:10.1080/00223980.2013.827614

9. Marius WS, Sebastian R. Psychological Empowerment, job insecurity and employee engagement. SA J Ind Psych. 2010;36(1):1-8.

10. Joo BK, Lim DH, Kim S. Enhancing work engagement: the role of psychological capital, authentic leadership, and work engagement. Leadership Org Dev J. 2016;37(8):1117-1134. doi:10.1108/LODJ01-2015-0005 
11. Yi L, Feng W, Shenggang R, Yang D. Locus of control, psychological empowerment and intrinsic motivation relation to performance. J Manage Psychol. 2015;30(4):422-438. doi:10.1108/JMP-10-2012-0318

12. Janie B, Marius WS. Leadership empowering behavior, psychological empowerment, organizational citizenship behaviors and turnover intention in a manufacturing division. SA J Ind Psychol. 2015;41(1):1-14.

13. Seung HH, Gaeun S, Seung WY, Dong YY. Transformational leadership and knowledge sharing: mediating roles of employee's empowerment, commitment, and citizenship behaviors. $J$ Workplace Learn. 2016;28(3):130-149. doi:10.1108/JWL-09-2015-0066

14. Thomas KW, Velthouse BA. Cognitive elements of empowerment: an "Interpretive" model of intrinsic task motivation. Acad Manage Rev. 1990;15(4):666-681.

15. Ehrenberg RG. American higher education in transition. J Econ Perspect. 2012;26(1):193-216. doi:10.1257/jep.26.1.193

16. Jiri M, Katerina Z, Kveton $P$, et al. Occupational well-being among university faculty: a job demands-resources model. Res High Educ. 2018;59(3):325-348. doi:10.1007/s11162-017-9467-x

17. Zulfqur A, Valcke M, et al. Leadership and decision-making practices in public versus private universities in Pakistan. Asia Pac Educ Rev. 2016;17:147-159. doi:10.1007/s12564-016-9414-0

18. Arnold BB, Matthijs PB. Weekly work engagement and performance: a study among starting teachers. J Occup Organ Psych. 2010;83:189206. doi:10.1348/096317909X402596

19. Sawasn H, Ibrahim B, Jonathan M. Transformational leadership and innovation: the mediating role of knowledge sharing amongst higher education faculty. Int J Leadersh Educ. 2019;1-24.

20. Ugwu F, Onyishi I, Rodríguez-Sánchez A. Linking organizational trust with employee engagement: the role of psychological empowerment. Pers Rew. 2014;43(3):377-400. doi:10.1108/PR-11-2012-0198

21. McBride M, Skau K. Trust, empowerment, and reflection: essentials of supervision. J Curriculum Supervi. 1995;10(3):262-277.

22. Gretechen MS. Psychological empowerment in the workplace: dimensions, measurement, and validation. Acad Manage J. 1995;38 (5):1442-1465.

23. Chaoping L, Xiaoxuan L, Kan S, Xuefeng C. Psychological empowerment measurement and its effect on employee work attitude in China. Acta Psychol Sinica. 2006;38(1):99-106.

24. Wilmar S, Arnold B Utrecht work engagement scale. Available from: https://www.wilmarschaufeli.nl/publications/Schaufeli/Test\%20Manuals/ Test manual_UWES_English.pdf. Accessed February 13, 2019.

25. Yiwen Z, Yiqun G. The Chinese version of Utrecht work engagement scale: an examination of reliability and validity. Chin J Clin Psych. 2005;13(3):268-270.
26. Jean-Sébastien B, Patrick G, Heather SL. Testing the structure of psychological empowerment: does gender make a difference? Educ Psychol Meas. 2004;64(5):861-877. doi:10.1177/0013164404264840

27. Rebecca JC, Jennifer DS, Nancy EP. Teachers' psychological functioning in the workplace: exploring the roles of contextual beliefs, need satisfaction, and personal characteristics. J Educ Psychol. 2016;108(6):788-799. doi:10.1037/edu0000088

28. Orit AU, Rinat AE. Teacher perceptions of empowerment and promotion during reforms. Int J Educ Manag. 2018;32(1):155-170. doi:10.1108/IJEM-01-2017-0002

29. Bhatnagar J. Management of innovation: role of psychological empowerment, work engagement and turnover intention in the Indian context. Int J Hum Resour Man. 2012;23:928-951. doi:10.1080/09585192.2012. 651313

30. Altbach PG. Harsh realities: the professoriate in the twenty-first century. In: Altbach PG, Patricia JG, Robert OB, editors. American Higher Education in the Twenty-First Century: Social, Political, and Economic Challenges. Baltimore: JHU Press; 2011:227-253.

31. Richard L. Leading the university: the roles of trustees, presidents, and faculty. Change. 2013;45(1):24-32. doi:10.1080/00091383.2013.749144

32. Judith MG, Ann EA. Rethinking academic traditions for twenty-firstcentury faculty. AAUP J Acad Freedom. 2010;1:1-20.

33. Bruce WS. The myth of shared governance in higher education. Int $J$ Organ Theor Behav. 2011;14(2):200-235. doi:10.1108/IJOTB-14-022011-B004

34. Mary MB. Making share governance work: strategies and challenges. Pedagogy. 2011;11(3):562-569. doi:10.1215/15314200-1302795

35. Nancy BK. Share governance and the sustainable college. Int $J$ Sustain High Educ. 2014;15(1):63-83.

36. Manjari S, Anita S. The relationship between psychological empowerment and innovative behavior. Int J Pers Psych. 2012;11:127-137.

37. Xiujun S. Psychological empowerment on job performance - mediating effect of job satisfaction. Psychology. 2016;7:584-590. doi: $10.4236 /$ psych.2016.74060

38. Janet L, Molly O, Alli B. Faculty organizational commitment and citizenship. Rew High Educ. 2012;53(3):325-352. doi:10.1007/ s11162-011-9230-7

39. Heather KL, Michael PL. Building empowering work environments that foster civility and organizational trust: testing an intervention. Nurs Res. 2012;61(5):316-325. doi:10.1097/NNR.0b013e318265a58d

40. O’Meara K, Mark R, Alexandra K, Kristen C. Faculty learning matters: organizational conditions and contexts that shape faculty learning. Innov High Educ. 2017;42(4):355-376. doi:10.1007/ s10755-017-9389-8
Psychology Research and Behavior Management

\section{Publish your work in this journal}

Psychology Research and Behavior Management is an international, peer-reviewed, open access journal focusing on the science of psychology and its application in behavior management to develop improved outcomes in the clinical, educational, sports and business arenas. Specific topics covered in the journal include: Neuroscience, memory and decision making; Behavior modification and management; Clinical applications; Business and sports performance management; Social and developmental studies; Animal studies. The manuscript management system is completely online and includes a very quick and fair peer-review system, which is all easy to use. Visit http://www. dovepress.com/testimonials.php to read real quotes from published authors. 